\title{
Contrasting responses of Intermountain West grasses to soil nitrogen
}

\author{
THOMAS A. MONACO*, DOUGLAS A. JOHNSON, JEANETTE M. NORTON, THOMAS A. JONES, KEVIN J. \\ CONNORS, JAY B. NORTON, AND MARGARET B. REDINBAUGH
}

Authors are Ecologist and Plant Physiologist, USDA-ARS Forage and Range Research Lab., Utah State Univ., Logan, Ut 84322-6300; Associate Professor, Plants, Soils, and Biometeorology Depart., Utah State Univ., Logan, Ut 84322-4820; Geneticist, Plant Physiologist, USDA-ARS Forage and Range Research Lab., Utah State Univ., Logan, Ut 84322-6300, Postdoctoral Research Associate, Plants, Soils, and Biometeorology Depart., Utah State Univ., Logan, Ut 84322-4820, and Molecular Geneticist, USDA-ARS Corn and Soybean Research, Wooster, Ohio 44691-4096.

\begin{abstract}
The mechanisms responsible for soil- $\mathrm{N}$-mediated species replacement of native perennial grasses by the invasive annual grasses cheatgrass (Bromus tectorum $\mathbf{L}$.) and medusahead (Taeniatherum caput-medusae [L.] Nevski) on rangelands are not completely understood. In addition, the contributions of distinct forms of inorganic $\mathrm{N}$ (i.e., $\mathrm{NH}_{4}{ }^{+}$and $\mathrm{NO}_{3}{ }^{-}$) to these shifts in species composition are currently unclear. Consequently, we conducted a greenhouse experiment to test 2 hypotheses: 1) that low $\mathbf{N}$ availability reduces growth (root and shoot) and $\mathbf{N}$ allocation of invasive annual seedlings more than native perennial species, and 2) that seedling growth and $\mathbf{N}$ allocation of invasive annual grasses is more responsive than native perennial grasses when supplied with $\mathrm{NO}_{3}^{-}$relative to $\mathrm{NH}_{4}^{+}$. We grew seedlings of 2 annual grasses and the native perennial grasses bluebunch wheatgrass (Pseudoroegneria spicata [Pursh] A. Löve), and 4 populations of squirreltail (Elymus elymoides [Raf.] Swezey; $E$. multisetus [J.G. Smith] M.E. Jones) in separate pots and exposed them to treatments differing in $\mathbf{N}$ form and availability for $\mathbf{1 7}$ weeks. Unexpectedly, root and shoot growth of annual grasses were equal or greater than native perennial grasses under low $\mathbf{N}$ availability. Annual grasses took up more $\mathrm{NO}_{3}{ }^{-}$and allocated more growth and $\mathbf{N}$ to shoots than the perennial grasses $(\mathrm{P}<$ $0.05)$. Perennial grasses had significantly greater root:shoot dry mass ratios than the invasive annual grasses across treatments ( $P$ $<0.05$ ). Invasive annual and native perennial grasses both had greater $(P<0.05)$ shoot and root mass and allocated more $\mathrm{N}$ to these structures when supplied with $\mathrm{NO}_{3}^{-}$relative to $\mathrm{NH}_{4}{ }^{+}$. The ecological implications of these growth and $\mathrm{N}$ allocation patterns in response to $\mathbf{N}$ availability and form provide important clues regarding the specific traits responsible for differences in competitive ability between invasive annual and native perennial grasses on semiarid rangelands.
\end{abstract}

Key Words: native perennial grass, invasive annual grass, nitrogen availability, nitrogen form, carbon-to-nitrogen ratio $(\mathrm{C}: \mathrm{N})$, seedling development, root development.

Research was funded by USDA-ARS and USDA-CSREES Grant No. 97 38300-4892. We thank E. Schupp, J. Young, and J. Krueger for insightful reviews of an earlier draft of the manuscript.

*Corresponding author and offprint requests: email:tmonaco@cc.usu.edu

Manuscript accepted 21 Jul. 02.

\section{Resumen}

Los mecanismos mediados por el nitrógeno del suelo responsables del reemplazo en pastizales de especies de zacates nativos perennes por los zacates invasores anuales "Cheatgrass" (Bromus tectorum L.) y 'Medusahead" no están completamente entendidos. Además, la contribución de las distintas formas de nitrógeno inorgánico $\left(\mathrm{NH}_{4}{ }^{+}\right.$y $\left.\mathrm{NO}_{3}{ }^{-}\right)$a estos cambios de composición de especies actualmente no esta clara. Consecuentemente, condujimos dos experimentos en invernadero para probar 2 hipótesis; 1) Una baja disponibilidad de $\mathbf{N}$ reduce el crecimiento (de raíz y tallos) y la distribución de $\mathrm{N}$ de las plántulas del zacate invasor anual más que en las especies perennes y 2) el crecimiento de las plántulas y la distribución de $\mathbf{N}$ de los zacates invasores anuales presentan una mayor respuesta que los zacates nativos perennes al suministro de $\mathrm{NO}_{3}{ }^{-}$en relación a $\mathrm{NH}_{4}{ }^{+}$. Durante 17 semanas desarrollamos plántulas de los dos zacates anuales y de los zacates nativos perennes "Bluebunch wheatgrass" (Pseudoroegneria spicata [Pursh] A. Löve) y de 4 poblaciones de "Squirreltail" (Elymus elymoides [Raf.] Swezey; E. multisetus [J.G. Smith] M.E. Jones), las plantas crecieron en macetas separadas y expuestas a diferentes formas y disponibilidad de $\mathbf{N}$. En una baja disponibilidad de $\mathbf{N}$ el crecimiento de raíz y tallos de los zacates anuales fue inesperadamente igual o mayor que el de los zacates nativos perennes. Los zacates anuales absorbieron más $\mathrm{NO}_{3}{ }^{-}$y asignaron mas crecimiento y $\mathrm{N}$ a los tallos que los zacatea nativos perennes $(P<\mathbf{0 . 0 5})$. Los zacates perennes tuvieron una relación de biomasa seca raíz:tallo mayor que los zacates invasores anuales, esto se presento en todos los tratamientos $(P<$ 0.05). Tanto los zacates anuales invasores como los nativos perennes tuvieron una mayor $(P<0.05)$ biomasas de tallos $y$ raíces y asignaron mas nitrógeno a estas estructuras cuando fueron suministrados con $\mathrm{NO}_{3}^{-}$en relación a $\mathrm{NH}_{4}{ }^{+}$. Las implicaciones ecológicas de estos patrones de crecimiento y distribución de $\mathbf{N}$ en respuesta a la forma $\mathbf{y}$ disponibilidad de $\mathbf{N}$ provee importantes indicios con respecto a las características específicas responsables de las diferencias en la capacidad competitiva entre los zacates anuales invasores y los nativos perennes de los pastizales semiáridos.

Cheatgrass (Bromus tectorum L.) and medusahead (Taeniatherum caput-medusae [L.] Nevski) are cool-season invasive annual grasses that reduce productivity, decrease biological diversity, and increase the frequency and intensity of wildfires on 
rangelands in the Intermountain West (Mack 1981, D'Antonio and Vitousek 1992, Young 1992). Repairing disturbed rangelands by re-establishing perennial grasses is extremely difficult because these annuals maintain dominance on disturbed sites by exhibiting high growth rates and seed production (Harris 1967, Wilson et al. 1974, Goebel et al. 1988, Aguirre and Johnson 1991). In addition, these invasive annual grasses are considered to be superior competitors for limited soil water (Harris and Wilson 1970, Melgoza et al. 1990) and nitrogen (N) (Dakheel et al. 1993, Link et al. 1995).

Soil $\mathrm{N}$ is a particularly important resource because its availability is inherently low under stable community conditions and may increase up to 12-fold following wildfire disturbance (Blank et al. 1994, 1996). Although many soil nutrients are important to plants, the availability of $\mathrm{N}$ most often limits productivity and intensifies competition among species in plant communities (McLendon and Redente 1991, 1992, Tilman and Wedin 1991). For example, field research suggests that addition of inorganic $\mathrm{N}$ to disturbed rangelands increases the relative abundance of cheatgrass (Wilson et al. 1966, Paschke et al. 2000), while reductions in $\mathrm{N}$ availability generally increases the relative abundance of perennials (Paschke et al. 2000). Reductions in soil $\mathrm{N}$ have also been shown to improve the competitive ability of bluebunch wheatgrass (Pseudoroegneria spicata [Pursh] A. Löve) relative to that of the invasive species spotted knapweed (Centaurea maculosa Lam.) in pot experiments (Herron et al. 2001). In addition, availability of the most abundant soil mineral $\mathrm{N}$ forms (i.e., $\mathrm{NO}_{3}^{-}$or $\mathrm{NH}_{4}{ }^{+}$) may influence the relative establishment of invasive annual or perennial grasses. For example, Young et al. $(1995,1998)$ found that fertilizing rangelands with $\mathrm{NO}_{3}{ }^{-}$ enhanced seedling emergence and establishment of medusahead, while fertilization with $\mathrm{NH}_{4}{ }^{+}$did not. Results from these field experiments suggest that manipulation of $\mathrm{N}$ form and availability may enhance the success of seeding perennial grasses into disturbed rangelands infested with cheatgrass and medusahead.

The mechanisms responsible for these $\mathrm{N}$-mediated shifts in species dominance, however, are not completely understood. Defining these mechanisms requires evaluation of the specific growth and/or functional traits that are altered by $\mathrm{N}$ availability. Do invasive annual grasses perform better than perennial grasses under high soil $\mathrm{N}$ availability because annuals have higher relative growth rates (Poorter et al. 1990, Lambers and Poorter 1992)? Although evidence exists that demonstrates that cheatgrass and medusahead have higher relative growth rates than native perennial grasses (Arredondo et al. 1998), it is unclear whether these annuals will be favored under conditions of high $\mathrm{N}$ availability, which has been observed for annuals in other plant communities (e.g., Aerts and Berendse 1988). Conversely, does low $\mathrm{N}$ availability reduce growth rates of invasive annual grasses so that relative performance of annual and perennial grasses are similar? Or do invasive annual and desirable perennial grasses differ in their nutrient-use efficiency (Chapin 1980) and biomass partitioning to shoots and roots when grown in low and high $\mathrm{N}$ supply (Hirose 1987)? Answers to these questions may provide important clues regarding the specific traits responsible for differences in competitive ability between invasive annual and desirable perennial grass species. In addition, this information may help in identifying management options to improve the success of seeding perennial grass species into rangelands dominated by cheatgrass or medusahead.

Here we report on the results of a greenhouse experiment that compared seedling growth of 2 invasive annual grasses and 5 native perennial grasses in response to treatments differing in $\mathrm{N}$ form and availability. Specifically, we compared plant biomass and $\mathrm{N}$ allocation to shoots and roots, tiller number per plant, and plantinduced changes in inorganic soil $\mathrm{N}$ of species grown separately in pots. We tested the following 2 hypotheses: 1) that low $\mathrm{N}$ availability reduces growth (root and shoot) and $\mathrm{N}$ allocation of invasive annual seedlings more than native perennial grasses, and 2) that seedling growth and $\mathrm{N}$ allocation of invasive annual grasses is more responsive than native perennial grasses when supplied with $\mathrm{NO}_{3}{ }^{-}$relative to $\mathrm{NH}_{4}{ }^{+}$.

\section{Materials and Methods}

\section{Soils}

The soil for our study was excavated from Dugway Proving Grounds (40 $14^{\circ}$ $23^{\prime \prime} \mathrm{N}, 112^{\circ} 50^{\prime} 47^{\prime \prime} \mathrm{W}$ ) in Tooele County, Ut. to a maximum depth of about $60 \mathrm{~cm}$. The top $2 \mathrm{~cm}$ of soil and litter was discarded to avoid existing seeds on the soil surface. The soil was a coarse loamy Xeric Torriorhents and a member of the Medburn Series (Trickler et al. 2000). Soil $\mathrm{pH}$ in distilled water was 8.2 , and cation exchange capacity (CEC) was $7 \mathrm{cmol} \mathrm{kg}^{-1}$ soil. Total soil carbon $(\mathrm{C})\left(13 \mathrm{~g} \mathrm{~kg}^{-1}\right)$ and total soil $\mathrm{N}\left(1 \mathrm{~g} \mathrm{~kg}^{-1}\right)$ were determined by direct combustion with a LECO CHN1000 autoanalyzer (LECO Corp., St. Joseph, Mich.) ${ }^{1}$. Soil gravimetric water contents at -0.033 and $-1.50 \mathrm{MPa}$ were 6.9 and $3.6 \%$, respectively. Soil was passed through a $6-\mathrm{mm}$ sieve to remove rocks and organic debris and thoroughly mixed. Soil equivalent to $7 \mathrm{~kg}$ oven-dry weight was added to individual plastic pots $(20 \mathrm{~cm}$ tall $\times 18 \mathrm{~cm}$ diameter at the base and $22 \mathrm{~cm}$ diameter at the top $\approx 8$ liter) with foam plugs inserted in the drainage holes to keep soil within the pot. This experiment was conducted in a greenhouse without artificial lighting from January to May 2000.

The following 5 soil treatments were established prior to planting grass seedlings: 1$)$ control $=$ no $\mathrm{N}$ added, 2) straw = barley $\operatorname{straw}\left(1 \mathrm{mg} \mathrm{kg}^{-1}\right.$ soil $)$ ground to pass a $1-\mathrm{mm}$ screen and thoroughly mixed with soil, 3) $\mathrm{NH}_{4}{ }^{+}=10 \mathrm{mg}$ $\mathrm{N} \mathrm{kg}^{-1}$ soil added as $\left.\left(\mathrm{NH}_{4}\right)_{2} \mathrm{SO}_{4}, 4\right) \mathrm{NH}_{4}{ }^{+}$ $+\mathrm{I}$ (nitrification inhibitor) $=10 \mathrm{mg} \mathrm{N} \mathrm{kg}^{-1}$ soil added as $\left(\mathrm{NH}_{4}\right)_{2} \mathrm{SO}_{4}+37 \mathrm{ml}$ nitrapyrin (29\% a.i., (2-chloro-6(trichloromethyl) pyridine), and 5) $\mathrm{NO}_{3}{ }^{-}=$ $10 \mathrm{mg} \mathrm{N} \mathrm{kg}{ }^{-1}$ soil added as $\mathrm{Ca}\left(\mathrm{NO}_{3}\right)_{2}$. Nitrapyrin inhibits the first nitrification step of bacterial $\mathrm{NH}_{4}{ }^{+}$oxidation and temporarily ( $\sim 60$ days) stabilizes $\mathrm{NH}_{4}{ }^{+}$in soils. The purpose of the straw treatment was to decrease overall inorganic $\mathrm{N}$ availability by promoting microbial immobilization of inorganic N. A preliminary evaluation indicated that nearly all extractable inorganic $\mathrm{N}$ was immobilized in the straw treatment within 5 days when soil moisture was brought to field capacity $(6.9 \%)$. All treatments were randomly applied to 28 pots with $600 \mathrm{ml}$ of water 2 days before planting. In addition, treatments 3,4 , and 5 were re-applied at half the initial rate of $\mathrm{N}$ (5 mg kg-1 soil) with $300 \mathrm{ml}$ of water 10 weeks after planting seedlings.

Soils were initially analyzed to quantify treatment effects on soil $\mathrm{NH}_{4}{ }^{+}$and $\mathrm{NO}_{3}{ }^{-}$ at 2 days after treatments were applied by taking soil cores ( 0 to $7 \mathrm{~cm}$ depth $x 1.5 \mathrm{~cm}$ diameter) from a subset of 3 pots of each treatment, which were not included in the experiment. Plant-or-microbe induced changes on soil $\mathrm{NH}_{4}{ }^{+}$and $\mathrm{NO}_{3}{ }^{-}$were measured from 1 soil core $(0$ to $20 \mathrm{~cm}$ depth $\times 1.5 \mathrm{~cm}$ ) from each pot at week 5

\footnotetext{
Mention ot a trade name does not imply an endorsement or recommendation by USDA over similar products or companies not mentioned.
} 
and from a subsample of the whole pot after roots were removed at the end of the experiment (week 17). Soil removed by coring was replaced with air-dried soil. All soil analyses were performed according to methods described by Hart et al. (1994). Soil samples were kept chilled until they were thoroughly mixed and extracted with $2 \mathrm{M} \mathrm{KCl}$ within 4 hours. The $\mathrm{KCl}$ solutions were filtered through pre-leached filter paper and frozen until analyzed. Concentrations of $\mathrm{NO}_{3}^{-}$and $\mathrm{NH}_{4}{ }^{+}$were analyzed colorimetrically with a flow injection autoanalyzer (Lachet Instruments, Milwaukee, Wis.)

\section{Plants}

The perennial grasses native to western North America that were used in our experiment included 'Goldar' bluebunch wheatgrass (Pseudoroegneria spicata [Pursh] A. Löve), 2 populations of big squirreltail: Sand Hollow and Seaman's Gulch (Elymus multisetus [J.G. Smith] M.E. Jones), and 2 populations of bottlebrush squirreltail: Little Camas (E. elymoides [Raf.] Sweezey ssp. brevifolius) and Little Wood (E. elymoides ssp. elymoides). The invasive annual grasses used in our experiment included cheatgrass and medusahead. Seeds of these invasive annuals were collected in Cache County, Ut $\left(41^{\circ} 46^{\prime} 07^{\prime \prime} \mathrm{N}, 111^{\circ} 47^{\prime} 11^{\prime \prime} \mathrm{W}\right.$ for cheatgrass and $41^{\circ} 32^{\prime} 18^{\prime \prime} \mathrm{N}, 111^{\circ} 48^{\prime \prime}$ $00^{\prime \prime} \mathrm{W}$ for medusahead). The short-lived squirreltails and long-lived bluebunch wheatgrass typically compete with the invasive annuals used in our experiment in many regions of the Intermountain West. The 7 taxa are hereafter referred to as grasses for simplicity of discussion. Each grass was randomly assigned to 4 pots per treatment. Seeds of each grass were germinated on blotter paper and transplanted 4 $\mathrm{cm}$ from the edge of each pot in a circular pattern to establish 5 plants per pot. After plant establishment, pots were watered 3 times each week with a syringe. Beginning at week 3, soil water content was adjusted weekly to the predetermined field capacity (6.9\% gravimetric soil water content). In addition, $70 \mathrm{~g}$ of perlite (processed siliceous rock) was added to the surface of each pot at week 4 to minimize evaporative loss from the pots.

Plant growth and tissue $\mathrm{N}$ variables were assessed on harvested plants at the end of the experiment (week 17). Number of tillers plant ${ }^{-1}$ was counted to obtain a mean for the 5 plants in each pot. Aboveground biomass of all plants was harvested at the soil surface, and root biomass (including crowns) was separated from the soil by sieving and then washing with water. Shoot and root components for each pot were dried at $55^{\circ} \mathrm{C}$ for 5 days to obtain dry mass values and then ground with a miniature coffee mill to pass through a $0.7-\mathrm{mm}$ mesh screen. Concentrations of total $\mathrm{C}$ and $\mathrm{N}$ for shoots and roots were determined by direct combustion with a LECO CHN-2000 autoanalyzer (LECO Corp., St. Joseph, Mich.). The concentration of $\mathrm{N}$ was multiplied by dry mass values to determine the amount of $\mathrm{N}$ in roots and shoots. In addition, $\mathrm{C}$ and $\mathrm{N}$ concentrations were used to calculate the carbon-to-nitrogen ratio $(\mathrm{C}: \mathrm{N})$ in roots and shoots. Initial soil concentrations of $\mathrm{NH}_{4}{ }^{+}$and $\mathrm{NO}_{3}^{-}$were analyzed with one-way analysis of variance (ANOVA) and means separated with the Tukey HSD test. Differences between soil treatments, grasses, and their interaction for the soil and plant variables were analyzed by twoway ANOVA. Treatment differences within each grass were tested with the Tukey HSD test after a one-way ANOVA, and statistical significance is shown in figures and tables. Differences between grasses within a treatment were tested with the Tukey HSD test after a one-way ANOVA, and statistical significance is discussed in the Results section. Differences are referred to as 'significant' when $\mathrm{P}<0.05$. Comparisons between the control and straw treatment were used to evaluate $\mathrm{N}$ availability effects (Hypothesis 1). Seedling responses to the $\mathrm{NH}_{4}{ }^{+}+\mathrm{I}$ and $\mathrm{NO}_{3}{ }^{-}$treatments were used to contrast the effects of $\mathrm{N}$ form (Hypothesis 2).

\section{Results}

Treatments designed to produce distinct $\mathrm{N}$-forms were established within a few days after application (Table 1). Initial soil $\mathrm{NH}_{4}^{+}$was significantly higher in the $\mathrm{NH}_{4}^{+}$and $\mathrm{NH}_{4}^{+}{ }^{+}+\mathrm{I}$ treatments than in

Table 1. Mean $( \pm 1 \mathrm{SE}, \mathrm{n}=3$ ) soil concentration of $\mathrm{NH}_{4}{ }^{+}$and $\mathrm{NO}_{3}^{-}$measured 2 days after initially applying treatments. Means within the same column followed by different letters are significantly different $(P<$ 0.05).

\begin{tabular}{lcc}
\hline \hline Treatment & $\mathrm{NH}_{4}{ }^{+}$ & $\mathrm{NO}_{3}^{-}$ \\
\hline & $----\mathrm{mg} \mathrm{N} \mathrm{kg}^{-1}$ & soil) \\
Control & $0.8 \pm 0.1 \mathrm{a}$ & $0.3 \pm 0.1 \mathrm{a}$ \\
Straw & $0.9 \pm 0.1 \mathrm{a}$ & $1.4 \pm 0.4 \mathrm{a}$ \\
$\mathrm{NH}_{4}{ }^{+}$ & $24.7 \pm 0.4 \mathrm{~b}$ & $1.1 \pm 1.0 \mathrm{a}$ \\
$\mathrm{NH}_{4}{ }^{+}+\mathrm{I}$ & $23.0 \pm 1.4 \mathrm{~b}$ & $0.8 \pm 0.3 \mathrm{a}$ \\
$\mathrm{NO}_{3}{ }^{-}$ & $0.8 \pm 0.1 \mathrm{a}$ & $17.8 \pm 0.4 \mathrm{~b}$ \\
\hline
\end{tabular}

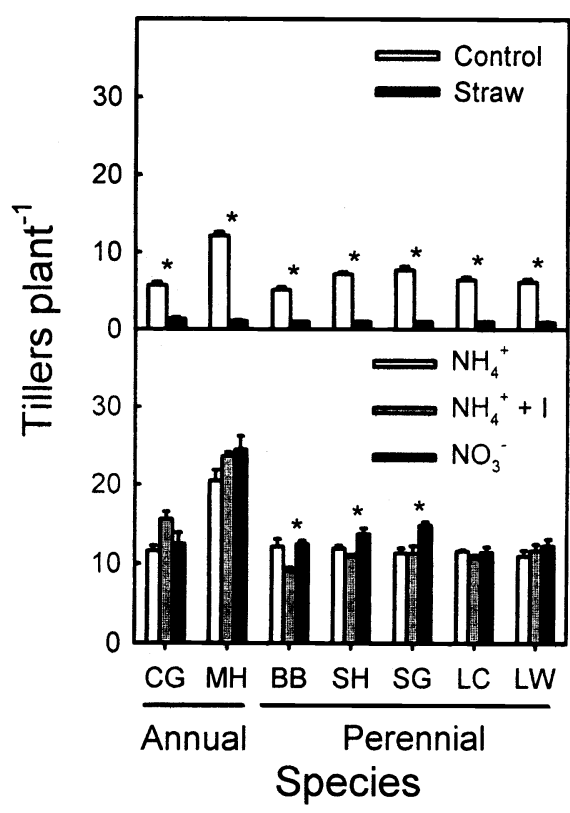

Fig. 1. Mean ( $\pm 1 \mathrm{SE})$ number of tillers plant $^{-1}$ for cheatgrass (CG), medusahead (MH), bluebunch wheatgrass (BB), and 4 squirreltails: Sandhollow (SH), Seaman's Gulch (SG), Little Camas (LC), and Little Wood $(L W)$. Plants were grown in 4 soil treatments for 17 weeks in a greenhouse to compare responses to $\mathrm{N}$ availability (control vs. straw) and $\mathrm{N}$ form $\left(\mathrm{NH}_{4}{ }^{+}+\mathrm{I}\right.$ vs. $\left.\mathrm{NO}_{3}{ }^{-}\right)$. Asterisks above bars denote significant $(P<0.05)$ differences between the respective 2-treatment comparisons.

the other treatments. By comparison, initial soil $\mathrm{NO}_{3}{ }^{-}$in the $\mathrm{NO}_{3}{ }^{-}$treatment was significantly greater ( $>20$ fold) than values of the other 4 treatments. Differences between the control and straw treatments for soil $\mathrm{NH}_{4}{ }^{+}$and $\mathrm{NO}_{3}{ }^{-}$were not initially detected. Plant growth and $\mathrm{N}$ allocation in the $\mathrm{NH}_{4}^{+}$treatment was usually intermediate to the $\mathrm{NH}_{4}{ }^{+}+\mathrm{I}$ and $\mathrm{NO}_{3}{ }^{-}$treatment.

Medusahead produced significantly more tillers per plant than any of the other species in all treatments except the straw treatment (Fig 1). Annual and perennial grass seedlings had similar numbers of tillers per plant within the straw treatment. A significant grass $x$ treatment interaction for number of tillers per plant indicated that grasses did not respond uniformly to $\mathrm{N}$ treatments (Table 2). Immobilizing soil $\mathrm{N}$ with the straw treatment significantly reduced the number of tillers per plant from values in the control by an average of $84 \%$ for the perennial grasses, $76 \%$ for cheatgrass, and $93 \%$ for medusahead. All species produced more tillers per plant in the $\mathrm{NO}_{3}{ }^{-}$treatment than in the $\mathrm{NH}_{4}^{+}+\mathrm{I}$ treatment except for cheatgrass. However, this $\mathrm{N}$ form effect was significant only for 
Table 2. Results of two-way analysis of variance (ANOVA) of growth variables for the $\mathbf{2}$ invasive annual and 5 native perennial grasses grown in 4 soil treatments for 17 weeks in a greenhouse. NS = not significant. Error term $\mathbf{~} \mathbf{=}=84$ (all tests).

\begin{tabular}{lccc}
\hline \hline Source of variation & $\begin{array}{c}\text { Treatment } \\
(\mathrm{df}=3)\end{array}$ & $\begin{array}{c}\text { Grasses } \\
(\mathrm{df}=6)\end{array}$ & $\begin{array}{c}\text { Treatment } x \text { Grasses } \\
(\mathrm{df}=18)\end{array}$ \\
\hline Tillers per plant & $\mathrm{P}<0.001$ & $\mathrm{P}<0.001$ & $\mathrm{P}<0.001$ \\
Shoot dry mass & $\mathrm{P}<0.001$ & $\mathrm{P}<0.001$ & $\mathrm{P}<0.001$ \\
Root dry mass & $\mathrm{P}<0.001$ & $\mathrm{P}<0.01$ & $\mathrm{NS}$ \\
Shoot $\mathrm{N}$ & $\mathrm{P}<0.001$ & $\mathrm{P}<0.001$ & $\mathrm{P}<0.001$ \\
Root $\mathrm{N}$ & $\mathrm{P}<0.001$ & $\mathrm{P}<0.001$ & $\mathrm{P}<0.001$ \\
Root:shoot ratio & $\mathrm{P}<0.001$ & $\mathrm{P}<0.001$ & $\mathrm{P}<0.01$ \\
Shoot $\mathrm{C}: \mathrm{N}$ ratio & $\mathrm{P}<0.001$ & $\mathrm{P}<0.001$ & $\mathrm{P}<0.001$ \\
Root C:N ratio & $\mathrm{P}<0.001$ & $\mathrm{NS}$ & $\mathrm{P}<0.001$ \\
5 week soil $\mathrm{NO}_{3}^{-}$ & $\mathrm{P}<0.001$ & $\mathrm{NS}$ & $\mathrm{NS}$ \\
5 week soil $\mathrm{NH}_{4}{ }^{+}$ & $\mathrm{P}<0.001$ & $\mathrm{NS}$ & $\mathrm{NS}$ \\
17 week soil $\mathrm{NO}_{3}{ }^{-}$ & $\mathrm{P}<0.001$ & $\mathrm{P}<0.05$ & $\mathrm{P}<0.01$ \\
17 week soil $\mathrm{NH}_{4}{ }^{+}$ & $\mathrm{NS}$ & $\mathrm{NS}$ & $\mathrm{NS}$ \\
\hline
\end{tabular}

bluebunch wheatgrass and Sandhollow and Seaman's Gulch big squirreltails.

Shoot dry mass of annual grass seedlings exceeded $(\mathrm{P}<0.05)$ that of the perennial grass seedlings for all treatments (Fig. 2). The straw treatment sustained significantly lower shoot dry mass than the control similarly for cheatgrass $(88 \%)$, medusahead $(91 \%)$, and the perennial species $(91 \%)$. Consequently, the significant species $\mathrm{x}$ treatment interaction for shoot dry mass (Table 2) was a result of greater shoot dry mass in the $\mathrm{NO}_{3}{ }^{-}$treatment compared to the $\mathrm{NH}_{4}{ }^{+}$treatment for both annual grasses and Sand Hollow big

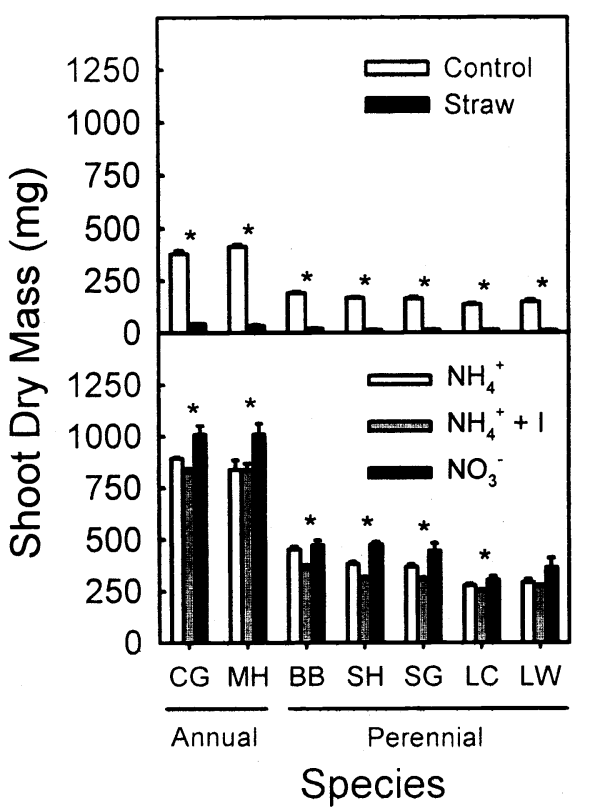
grasses. The absence of a significant grass $x$ treatment interaction for root dry mass indicated that annual and perennial seedlings responded equivalently to soil treatments (Table 2). Although not statistically significant, 4 of the 5 perennial Hollow big squirreltails, Little Camas botgrass) had greater root dry mass averaged across treatments than the invasive annual grasses. Low $\mathrm{N}$ availability in the straw treatment significantly reduced root dry mass by $92 \%$ from the control across all

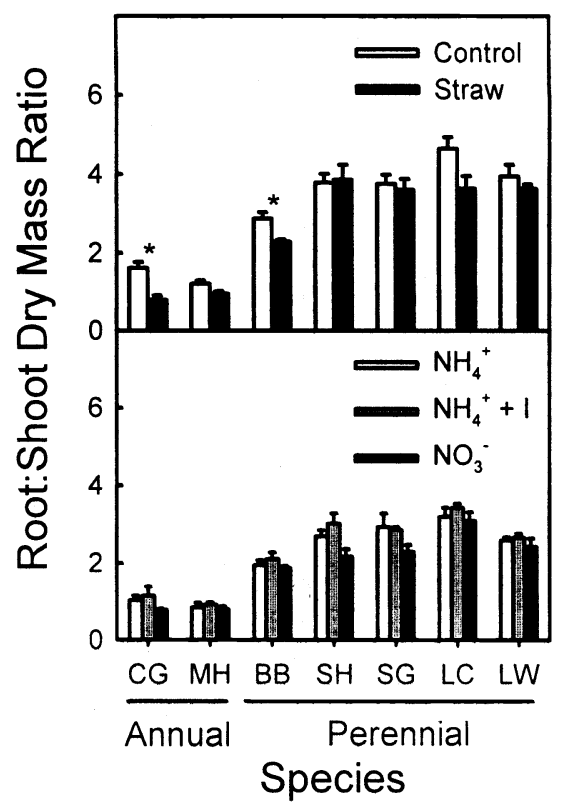
grasses (Seaman's Gulch and Sand tlebrush squirreltail, and bluebunch wheat-

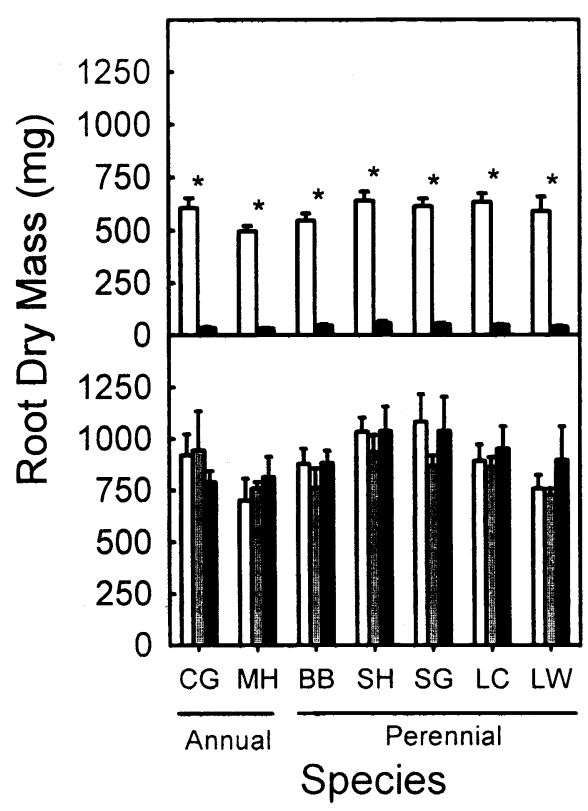

Fig. 2. Mean ( \pm 1 SE) shoot and root dry mass for cheatgrass (CG), medusahead (MH), bluebunch wheatgrass (BB), and 4 squirreltails: Sandhollow (SH), Seaman's Gulch (SG), Little Camas (LC), and Little Wood (LW). Plants were grown in 4 soil treatments for 17 weeks in a greenhouse to compare responses to $\mathrm{N}$ availability (control vs. straw) and $\mathbf{N}$ form $\left(\mathrm{NH}_{4}{ }^{+}\right.$ + I vs. $\left.\mathrm{NO}_{3}^{-}\right)$. Asterisks above bars denote significant $(\mathrm{P}<0.05)$ differences between the respective 2-treatment comparisons.
Fig. 3. Mean ( $\pm 1 \mathrm{SE})$ root:shoot dry mass ratio for cheatgrass (CG), medusahead (MH), bluebunch wheatgrass (BB), and 4 squirreltails: Sandhollow (SH), Seaman's Gulch (SG), Little Camas (LC), and Little Wood (LW). Plants were grown in 4 soil treatments for 17 weeks in a greenhouse to compare responses to $\mathbf{N}$ availability (control vs. straw) and $\mathrm{N}$ form $\left(\mathrm{NH}_{4}^{+}+\mathrm{I}\right.$ vs. $\left.\mathrm{NO}_{3}{ }^{-}\right)$. Asterisks above bars denote significant $(P<0.05)$ differences between the respective 2-treatment comparisons.

species (Fig. 2). In contrast, soil treatments that differed in $\mathrm{N}$ form did not significantly modify root dry mass.

Values for root:shoot dry mass ratio (RSR) of the invasive annual grasses were consistently lower $(P<0.05)$ than the native perennial grasses in each treatment (Fig. 3, Table 2). In addition, the 4 squirreltails consistently had greater RSR values than bluebunch wheatgrass. This significant grass $\mathrm{x}$ treatment interaction was a consequence of RSR values in the straw treatment being significantly lower than the control for cheatgrass and bluebunch wheatgrass, but none of the other 5 grasses. In contrast, no differences in RSR were observed between $\mathrm{N}$-form treatments for any grass.

Shoot $\mathrm{N}$ was generally greater in annual grasses, while root $\mathrm{N}$ was generally greater in perennial grasses (Fig. 4). For example, medusahead allocated more $\mathrm{N}$ to shoots than the perennials for all treatments $(P<0.05)$ except the straw treatment. Similarly, cheatgrass shoots contained more $\mathrm{N}$ than the squirreltails $(\mathrm{P}<$ 0.05 ), but not bluebunch wheatgrass, for all treatments. Medusahead roots had lower $\mathrm{N}$ content than all perennial grasses 

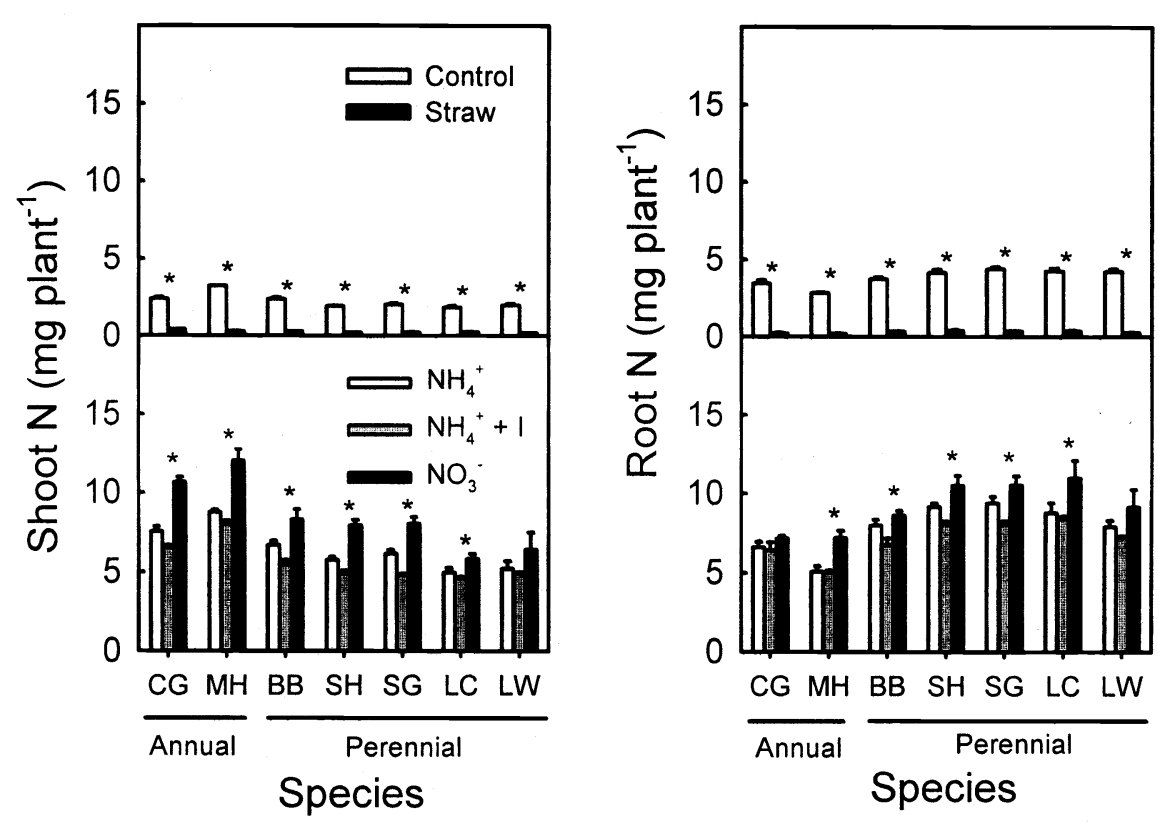

Fig. 4. Mean ( 1 SE) shoot and root $\mathbf{N}$ for (CG), medusahead (MH), bluebunch wheatgrass (BB), and 4 squirreltails: Sandhollow (SH), Seaman's Gulch (SG), Little Camas (LC), and Little Wood (LW). Plants were grown in 4 soil treatments for 17 weeks in a greenhouse to compare responses to $\mathrm{N}$ availability (control vs. straw) and $\mathrm{N}$ form $\left(\mathrm{NH}_{4}{ }^{+}+\mathrm{I}\right.$ vs. $\left.\mathrm{NO}_{3}{ }^{-}\right)$. Asterisks above bars denote significant $(\mathrm{P}<0.05)$ differences between the respective 2 treatment comparisons.

in the control and $\mathrm{NH}_{4}{ }^{+}$treatment $(\mathrm{P}<$ $0.05)$. In addition, root $\mathrm{N}$ of medusahead and cheatgrass was significantly less than Sandhollow and Seaman's Gulch big squirreltails, and Little Wood bottlebrush squirreltail in all treatments except the straw treatment. The straw treatment significantly reduced shoot and root $\mathrm{N}$ from the control by a similar percentage for all grasses. Shoots contained more $\mathrm{N}$ in the $\mathrm{NO}_{3}{ }^{-}$treatment than in the $\mathrm{NH}_{4}^{+}+\mathrm{I}$ treatment for all grasses except Little Wood bottlebrush squirreltail. Similarly, all grasses except Little Wood bottlebrush squirreltail and cheatgrass allocated significantly more $\mathrm{N}$ to roots in the $\mathrm{NO}_{3}{ }^{-}$ treatment than in the $\mathrm{NH}_{4}{ }^{+}+\mathrm{I}$ treatment. Consequently, we attribute the significant treatment $\mathrm{x}$ grass interactions for shoot and root $\mathrm{N}$ (Table 2) to species differences in response to the $\mathrm{NO}_{3}^{-}$and $\mathrm{NH}_{4}{ }^{+}+\mathrm{I}$ treatments, because these grasses demonstrated similar reductions from the control when inorganic soil $\mathrm{N}$ was immobilized by the straw treatment.

Invasive annual seedlings had greater $(\mathrm{P}$ $<0.05)$ shoot $\mathrm{C}: \mathrm{N}$ ratios than native perennial seedlings for all treatments (Fig. 5, Table 2). In the control treatment, shoot $\mathrm{C}: \mathrm{N}$ ratio of cheatgrass exceeded medusahead by $15 \%$ and the average for the perennial grasses by $47 \%$. Root $\mathrm{C}: \mathrm{N}$ ratios were generally greater for annual than root $\mathrm{C}: \mathrm{N}$ ratio was only significantly greater than both bottlebrush squirreltails. Average root $\mathrm{C}: \mathrm{N}$ pooled across species was significantly higher in the control treatment than in the straw $(6 \%), \mathrm{NH}_{4}{ }^{+}$ $(28 \%), \mathrm{NH}_{4}{ }^{+}+\mathrm{I}(26 \%)$, and $\mathrm{NO}_{3}{ }^{-}(37 \%)$ treatments. Low $\mathrm{N}$ availability produced by the straw treatment consistently reduced shoot $\mathrm{C}: \mathrm{N}$ ratios from the control for all grasses. By comparison, cheatgrass and medusahead were the only grasses to show a significant response to $\mathrm{N}$ form with lower shoot $\mathrm{C}: \mathrm{N}$ ratios in the $\mathrm{NO}_{3}{ }^{-}$ than $\mathrm{NH}_{4}{ }^{+}+$I treatment.

The 5 treatments produced significantly different soil $\mathrm{NH}_{4}{ }^{+}$and $\mathrm{NO}_{3}{ }^{-}$values measured at week 5; however, grasses had similar effects on soil $\mathrm{NH}_{4}{ }^{+}$and $\mathrm{NO}_{3}{ }^{-}$at this date (Fig. 6, Table 2). The amount of soil $\mathrm{NO}_{3}{ }^{-}$averaged across grasses remaining in the $\mathrm{NO}_{3}{ }^{-}$treatment at week 5 exceeded the straw treatment by $92 \%$, the control treatment by $68 \%$, the $\mathrm{NH}_{4}{ }^{+}$treatment by $32 \%$, and the $\mathrm{NH}_{4}{ }^{+}+\mathrm{I}$ treatment by $73 \%$. Soil $\mathrm{NH}_{4}{ }^{+}$values measured at week 5 were significantly greater in the $\mathrm{NH}_{4}{ }^{+}+$I treatment $\left(3.1 \mathrm{mg} \mathrm{kg}^{-1}\right)$ than values for the other treatments (range $=0.04$ to $0.18 \mathrm{mg} \mathrm{kg}^{-1}$ ) measured at week 5 . However, by week 17 , values for soil $\mathrm{NH}_{4}{ }^{+}$did not significantly differ between treatments or grasses (range $=0.13$ to 0.20 $\mathrm{mg} \mathrm{kg}^{-1}$ ) (Table 2). In contrast, at week 17, (0.05) than all grasses; however, cheatg 0.05 ) than all grasses; however, cheatgrass
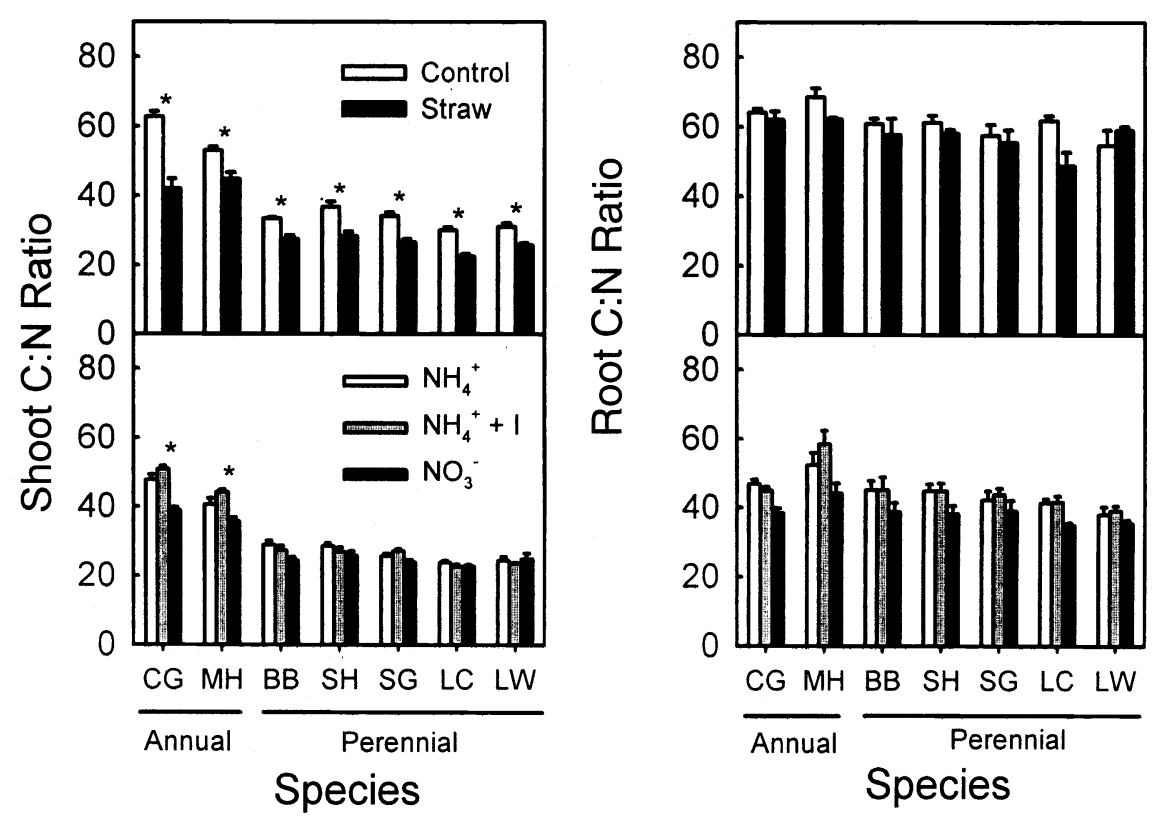

Fig. 5. Mean ( $\pm 1 \mathrm{SE})$ shoot and root carbon:nitrogen concentration ratio (C:N) for cheatgrass (CG), medusahead (MH), bluebunch wheatgrass (BB), and 4 squirreltails: Sandhollow (SH), Seaman's Gulch (SG), Little Camas (LC), and Little Wood (LW). Plants were grown in 4 soil treatments for 17 weeks in a greenhouse to compare responses to $\mathbf{N}$ availability (control vs. straw) and $\mathrm{N}$ form $\left(\mathrm{NH}_{4}{ }^{+}+\mathrm{I}\right.$ vs. $\left.\mathrm{NO}_{3}{ }^{-}\right)$. Asterisks above bars denote significant $(P<0.05)$ differences between the respective 2-treatment comparisons. 

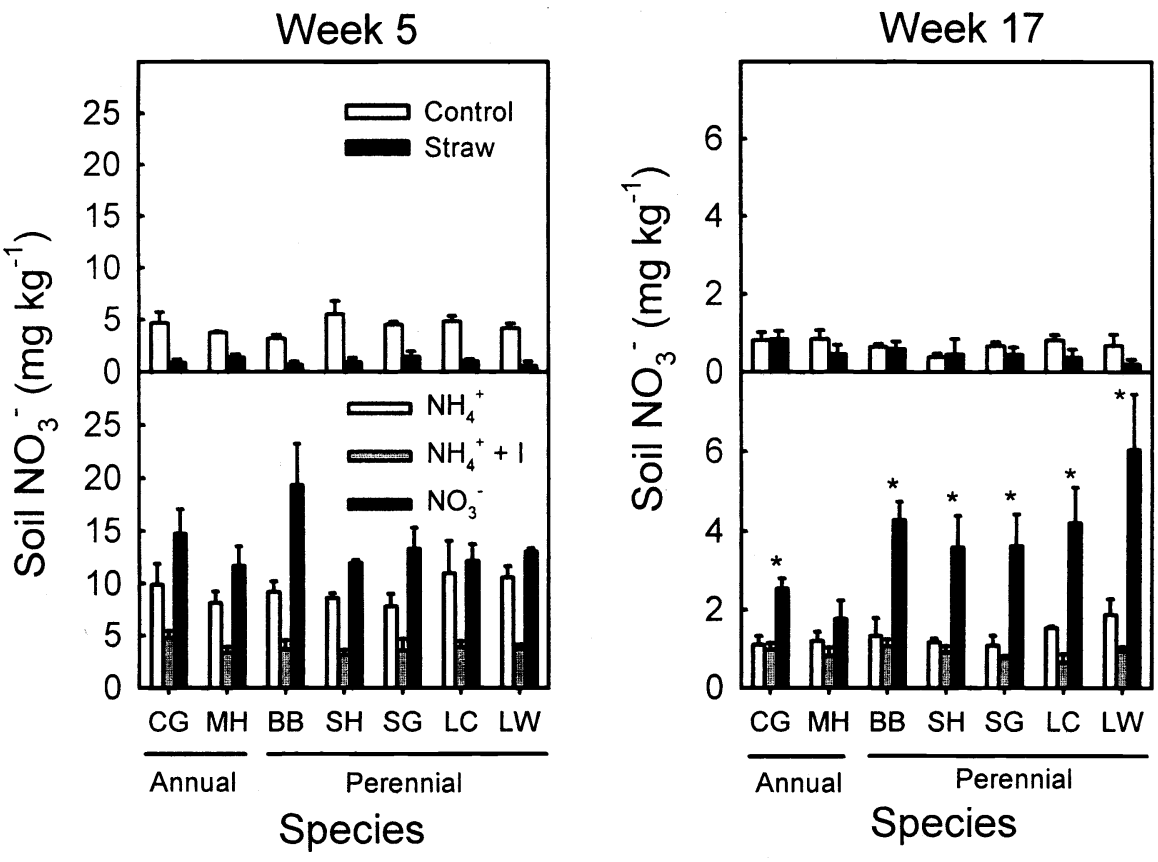

Fig. 6. Mean ( $\pm 1 \mathrm{SE}$ ) concentration of $\mathrm{NO}_{3}^{-}$measured in soils at 5 weeks and 17 weeks for cheatgrass (CG), medusahead (MH), bluebunch wheatgrass (BB), and 4 squirreltails: Sandhollow (SH), Seaman's Gulch (SG), Little Camas (LC), and Little Wood (LW). Plants were grown in 4 soil treatments for 17 weeks in a greenhouse to compare responses to $N$ availability (control vs. straw) and $\mathrm{N}$ form $\left(\mathrm{NH}_{4}^{+}+\mathrm{I}\right.$ vs. $\left.\mathrm{NO}_{3}{ }^{-}\right)$. Asterisks above bars denote significant $(\mathrm{P}<0.05)$ differences between the respective 2 -treatment comparisons.

treatment, grasses, and their interaction had significant effects on soil $\mathrm{NO}_{3}{ }^{-}$(Table 2). Significantly more $\mathrm{NO}_{3}{ }^{-}$remained in soils of the $\mathrm{NO}_{3}{ }^{-}$treatment than the other 4 treatments for all grasses except medusahead. Grasses had similar effects on soil $\mathrm{NO}_{3}{ }^{-}$for all treatments except the $\mathrm{NO}_{3}{ }^{-}$treatment, where cheatgrass and medusahead generally reduced soil $\mathrm{NO}_{3}{ }^{-}$ more than the perennial grasses. However, the only significant difference between species for soil $\mathrm{NO}_{3}{ }^{-}$in the $\mathrm{NO}_{3}{ }^{-}$treatment was between medusahead and Little Wood bottlebrush squirreltail.

\section{Discussion}

Low $\mathrm{N}$ availability induced by microbial immobilization drastically reduced plant growth and $\mathrm{N}$ allocation to roots and shoots of all species. Moreover, the magnitude of these reductions was similar for all species, even though invasive annuals produced more tillers per plant, had greater shoot dry mass, and allocated more $\mathrm{N}$ to shoots than perennials. On the basis of these results, we reject the hypothesis that low $\mathrm{N}$ availability reduces growth (root and shoot) and $\mathrm{N}$ allocation of invasive annual seedlings more than native perennial species, because low $\mathrm{N}$ availability affected both annual and perennial species similarly.

All grasses generally produced more tillers and allocated additional growth and $\mathrm{N}$ to shoots and roots when supplied $\mathrm{NO}_{3}{ }^{-}$ compared to $\mathrm{NH}_{4}{ }^{+}$. Thus, we did not observe a clear distinction between annual and perennial grasses when their relative responses to distinct forms of inorganic $\mathrm{N}$ were compared. Consequently, the hypothesis that seedling growth and $\mathrm{N}$ allocation of invasive annual grasses is more responsive than native perennial grasses when supplied with $\mathrm{NO}_{3}^{-}$relative to $\mathrm{NH}_{4}{ }^{+}$was also rejected.

\section{Low $\mathbf{N}$ availability}

The rejection of Hypothesis 1 necessitates an explanation for the greater or equal performance of invasive annual grasses compared with that of the native perennial grasses under low soil $\mathrm{N}$ availability. This hypothesis rejection also suggests that caution should be taken when assuming that low nutrient demand of perennial grasses translates into greater competitive ability under low $\mathrm{N}$ conditions. Others have observed similar results to ours in short-term pot experiments (Berendse et al. 1992, van der Werf et al. 1993a, 1993b), wherein fast and slowgrowing grass species responded similarly to low soil $\mathrm{N}$. These authors explained that fast-growing grasses initially allocate more carbon to root growth and take up more $\mathrm{N}$ per plant than slow-growing grasses, allowing them to produce more biomass than the slow-growing grasses under low $\mathrm{N}$ availability. However, $\mathrm{N}$ availability per plant (i.e., in pots) decreased through time for both species and led to decreased relative growth rates and increased allocation to roots (Hirose 1987), especially in the slow-growing species (van der Werf et al. 1993b). This response pattern closely resembles the responses observed in our experiment because the fast-growing invasive annual grasses (Arredondo et al. 1998) primarily allocated $\mathrm{N}$ and biomass to shoots, whereas allocation was primarily to roots in the slow-growing native perennial grasses. Thus, high growth rates in the invasive annuals may have enabled them to better exploit the limiting $\mathrm{N}$ supply in pots and perform relatively better or equal than the slow-growing native perennial grasses. Furthermore, our results indicate that the slower-growing native perennials allocated their acquired $\mathrm{N}$ and growth to roots at the expense of whole-plant growth, even though these slow-growing species are likely to be functioning closer to their 'optimal growth and metabolic rate' when soil $\mathrm{N}$ is limiting (e.g., Chapin et al. 1987).

Our results also demonstrated that the magnitude of differences in growth responses between annual and perennial grasses was lower when $\mathrm{N}$ was drastically reduced by microbial immobilization compared to the control or the $3 \mathrm{~N}$ addition treatments. Thus, under low soil $\mathrm{N}$, the relative performance of these 2 groups may be similar enough so that the slowgrowing native perennial grasses are capable of gradually replacing the fast-growing invasive annual grasses. For example, medusahead produced nearly twice as many tillers per plant than cheatgrass and the perennial grasses in the control treatment, but in the straw treatment, tiller numbers for medusahead were markedly reduced and comparable to the other species. Reducing the number of tillers per plant would also greatly limit the number of viable seeds to supplement invasive annual seedbanks. Limitations on seed production may be partly responsible for the reductions in cheatgrass (Redente et al. 1992, Paschke et al. 2000) and medusahead (Young et al. 1995, 1998) on semiarid rangelands when soil $\mathrm{N}$ is maintained low for multiple (3 to 5) years. 
Although invasive annual grasses showed equal or greater efficiency in acquiring soil $\mathrm{N}$ under limiting $\mathrm{N}$ conditions, the native perennial grasses displayed more efficient $\mathrm{N}$ use after $\mathrm{N}$ was acquired. Two main traits are generally recognized as contributing to competitive ability and efficient $\mathrm{N}$ use under nutrientpoor conditions: 1) relatively high investment of biomass in roots to enhance absorption (Chapin et al. 1987, Tilman 1988) and 2) low nutrient losses (leaf retention) and increased nutrient resorption from senescing leaves (Grime 1979, Berendse et al. 1992). We observed that the native perennial grasses in the present experiment displayed both of these traits to a greater extent than the invasive annual grasses. Perennial grasses primarily allocated $\mathrm{N}$ and biomass to roots and thus had significantly higher root:shoot ratios than the invasive annual grasses. Moreover, consistently lower leaf $\mathrm{C}: \mathrm{N}$ ratios, as observed in the native perennial grasses, reflected greater overall nutrient retention (per unit mass) and investment in perennial structures compared to the invasive annual grasses. Similarly, Redente et al. (1992) found that low soil $\mathrm{N}$ generated lower $\mathrm{C}: \mathrm{N}$ ratios and greater tissue $\mathrm{N}$ concentrations in late-seral, perennial species compared to early-seral, annual species in semiarid, shrub-steppe rangeland. These observations coupled with much greater leaf longevity in the perennial grasses help define the mechanism by which perennial grasses may increase their relative competitive ability through time when $\mathrm{N}$ availability remains limiting (e.g., Parrish and Bazzaz 1982, Schläpfer and Ryser 1996), even though the annual grasses have higher growth rates and $\mathrm{N}$ uptake efficiency in the short term. Thus, managing for continually low $\mathrm{N}$ availability appears to be a potential integrated weed management tool (e.g., Masters and Sheley 2001) to reduce the productivity of invasive annual grasses and provide a competitive advantage to slowgrowing native perennial grasses (Grime 1979, McGraw and Chapin 1989).

\section{High N Availability}

It has been known for many years that $\mathrm{N}$ fertilization on rangelands in the Intermountain West facilitates the replacement of native perennial grasses by invasive annual grasses such as cheatgrass (Wilson et al. 1966). Accordingly, current theories hypothesize that fluctuating resource availability is the key factor controlling the relative susceptibility of plant communities to invasive plant species (Huenneke et al. 1990, Milberg et al.
1999, Davis et al. 2000). Our results agree with previous reports that annual grasses are capable of maintaining higher growth rates than perennial grasses (Garnier 1992) through greater leaf $\mathrm{N}$ concentrations (Chapin 1980) and higher $\mathrm{N}$ absorption rate (Garnier and Vancaeyzeele 1994); however, invasive annual grasses have shorter growing periods (Jackson and Roy 1986). Higher growth rates enabled invasive annual species to take advantage of high $\mathrm{N}$ availability (e.g., Aerts and Berendse 1988) and produce significantly more shoot dry mass with higher $\mathrm{C}: \mathrm{N}$ ratios than the native species, regardless of treatment. In contrast, perennial grasses demonstrated less plasticity in shoot dry mass under high $\mathrm{N}$ availability. Greater responsiveness of invasive annual seedlings to high $\mathrm{N}$ availability, thus, increases their competitive ability and facilitates the replacement of desirable perennial grasses (e.g., Tilman 1982, McLendon and Redente 1992, Paschke et al. 2000), especially when inorganic soil $\mathrm{N}$ remains abundant (e.g., Bazzaz 1979 , Tilman 1987).

Our results suggest that efficient $\mathrm{N}$ uptake demonstrated by the invasive annual grasses compared to the native perennials resulted in greater depletion of soil $\mathrm{NO}_{3}{ }^{-}$within the $\mathrm{NO}_{3}{ }^{-}$treatment during the experiment. On the contrary, soil $\mathrm{NH}_{4}{ }^{+}$was depleted to similar levels by annual and perennial species during the experiment. These observations lead to the intriguing question: were the invasive annual grasses more responsive at both high and low soil availability because they were more efficient at extracting soil $\mathrm{NO}_{3}{ }^{-}$? If the answer is yes, it provides a plausible explanation for why increased availability of $\mathrm{NO}_{3}{ }^{-}$, but not $\mathrm{NH}_{4}{ }^{+}$, increased seedling establishment of medusahead from existing seedbanks (Young et al. 1995), while reducing nitrification (decreased availability of $\mathrm{NO}_{3}{ }^{-}$) effectively curtailed medusahead plant density (Young et al. 1998). It, therefore, seems likely that the availability of different forms of inorganic $\mathrm{N}\left(\mathrm{NO}_{3}{ }^{-}\right.$and $\mathrm{NH}_{4}{ }^{+}$) may be a way of effectively manipulating germination of invasive annual and desirable perennial species (e.g., Evans and Young 1975, Blank et al. 1994, Young et al. 1997). However, additional research is required to better define the positive or negative effects of distinct forms of inorganic $\mathrm{N}$ on germination for both invasive annual and native perennial grasses while controlling the inherent differences in seed dormancy that may exist within seedbanks.

\section{Management Implications}

Species dominance has been experimentally shifted by $\mathrm{N}$ availability in many plant community types including mesic heathland (Aerts and Berendse 1988), abandoned cropland (Tilman 1984, Wilson and Gerry 1995), shrub-steppe rangeland in North America (Redente et al. 1992, Gillen and Berg 1998, Paschke et al. 2000) and Australia (Hobbs and Atkins 1988, Snyman 2002), and arid shrublands (Milberg et al. 1999). However, few experiments have directly examined the Great Basin species evaluated in our experiment. With increased awareness of the impacts of atmospheric $\mathrm{N}$ deposition in many regions of the world (Morecroft et al. 1994, Vitousek et al. 1997, Kirkham 2001), it is imperative that the potential impacts of modifications in soil $\mathrm{N}$ on species composition and competitive interactions are better understood for rangelands. Based on the results of our study, we suggest that 3 specific research emphases may provide critical information to advance our understanding of soil $\mathrm{N}$ relations in rangeland plants. First, species preferences for $\mathrm{N}$ forms in a soil environment should be evaluated in experiments in which $\mathrm{N}$ forms are varied independently from $\mathrm{N}$ availability. Second, experiments that characterize the resource requirements or demands of invasive annual and desirable perennial grasses should be conducted to examine hypotheses regarding how the competitive balance of these 2 species groups may be controlled by $\mathrm{N}$ availability. Third, rangeland plant responses to $\mathrm{N}$ form and availability need to be scaled-up to the level of plant communities by evaluating the potential functional differences in $\mathrm{N}$ cycling between plant communities dominated by invasive annual grasses and those dominated by desirable perennial grasses (e.g., Bolton et al. 1990, Svejcar and Sheley 2001, Evans et al. 2001).

\section{Literature Cited}

Aerts, R. and F. Berendse. 1988. The effect of increased nutrient availability on vegetation dynamics in wet heathlands. Vegetatio 76:63-69.

Aguirre, L and D.A. Johnson. 1991. Influence of temperature and cheatgrass competition on seedling development of two bunchgrasses. J. Range Manage. 44:347-354.

Arredondo, J.T., T.A. Jones, and D.A. Johnson. 1998. Seedling growth of Intermountain perennial and weedy annual grasses. J. Range Manage. 51:584-589. 
Bazzaz, F.A. 1979. The physiological ecology of plant succession. Ann. Rev. Ecol. Syst. 10:351-371.

Berendse, F., W. Th. Elberse, and R.H.M.E. Geerts. 1992. Competition and nitrogen loss from plants in grassland ecosystems. Ecol. 73:46-53.

Blank, R.R., L. Agraham, and J.A. Young. 1994. Soil heating, nitrogen, cheatgrass, and seedbed microsites. J. Range Manage. 47:33-37.

Blank, R.R., F.L. Allen, and J.A. Young. 1996. Influence of simulated burning of soillitter from low sagebrush, squirreltail, cheatgrass, and medusahead on water-soluble anions and cations. Int. J. Wildland Fire 6:137-143.

Bolton, H., Jr., J.L. Smith, and R.E. Wildung. 1990. Nitrogen mineralization potentials of shrub-steppe soils with different disturbance histories. Soil. Sci. Soc. Amer. J. 54:887-891.

Chapin, F.S., III. 1980. The mineral nutrition of wild plants. Annu. Rev. Ecol. Syst. 11:233-260.

Chapin, F.S., III, A.J. Bloom, C.B. Field, and R.H. Waring. 1987. Plant responses to multiple environmental factors. Biosci. 37:49-57.

Dakheel, A.J., S.R. Radosevich, and M.G. Barbour. 1993. Effects of nitrogen and phosphorus on growth and interference between Bromus tectorum and Taeniatherum asperum. Weed Res. 33:415-422.

D'Antonio, C.M. and P.M. Vitousek. 1992. Biological invasions by exotic grasses, the grass/fire cycle, and global change. Annu. Rev. Ecol. Syst. 23:63-87.

Davis, M.A., P.G. Grime, and K. Thompson. 2000. Fluctuating resources in plant communities: a general theory of invasibility. J. Ecol. 88:528-534.

Evans, R.A. and J.A. Young. 1975. Enhancing germination of dormant seeds of downy brome. Weed Sci. 23:354-357.

Evans, R.D., R. Rimer, L. Sperry, and J. Belnap. 2001. Exotic plant invasion alters nitrogen dynamics in an arid grassland. Ecol. Appl. 11:1301-1310.

Garnier, E. 1992. Growth analysis of congeneric annual and perennial grass species. J. Ecol. 80:665-675.

Garnier E. and S. Vancaeyzeele. 1994. Carbon and nitrogen content of congeneric annual and perennial grass species: relationships with growth. Plant Cell Environ. 17:399-407.

Gillen, R.L., and W.A. Berg. 1998. Nitrogen fertilization of a native grass planting in western Oklahoma. J. Range Manage. 51:436-441.

Goebel, C.J., M. Tazi, and G.A. Harris. 1988. Secar bluebunch wheatgrass as a competitor to medusahead. J. Range Manage. 41:88-89.

Grime, J.P. 1979. Plant strategies and vegetation processes. John Wiley and Sons, N.Y.

Harris, G.A. 1967. Some competitive relationships between Agropyron spicatum and Bromus tectorum. Ecol. Monogr. 37:89-111.
Harris, G.A. and A.M. Wilson. 1970. Competition for moisture among seedlings of annual and perennial grasses as influenced by root elongation at low temperature. Ecol. 51:530-534.

Hart, S.C., J.M. Stark, E.A. Davidson, and M.K. Firestone. 1994. Nitrogen mineralization, immobilization and nitrification. $\mathrm{p}$. 985-1018. In: R.W. Weaver, S. Angle, P. Bottomley, D. Bezdicek, S. Smith, A Tabatabai, and A. Wollum (eds.) Methods of soil analysis microbiological and biochemical properties, Third edition. Soil Sci. Soc. of Amer., Madison, Wis.

Herron, G.J., R.L. Sheley, B.D. Maxwell, and J.S. Jacobsen. 2001. Influence of nutrient availability on the interaction between spotted knapweed and bluebunch wheatgrass. Rest. Ecol. 9:326-331.

Hirose, T. 1987. A vegetative growth model: adaptive significance of phenotypic plasticity in matter partitioning. Funct. Ecol. 1:195-202.

Hobbs, R.J. and L. Atkins. 1988. Effect of disturbance and nutrient addition on native and introduced annuals in plant communities in the Western Australian wheatbelt. Aust. J. Ecol. 13:171-179.

Huenneke, L.F., S.P. Hamburg, R. Koide, H.A. Mooney, and P.M. Vitousek. 1990. Effects of soil resources on plant invasion and community structure in Californian serpentine grassland. Ecol. 71:478-491.

Jackson, L.E. and J. Roy. 1986. Growth patterns of Mediterranean annual and perennial grasses under simulated rainfall regimes of southern France and California. Acta Oecol. Ecol. Plant. 7:191-212.

Kirkham, F.W. 2001. Nitrogen uptake and nutrient limitation in six hill moorland species in relation to atmospheric nitrogen deposition in England and Wales. J. Ecol. 89:1041-1053.

Lambers, H. and H. Poorter. 1992. Inherent variation in growth rate between higher plants: a search for physiological causes and ecological consequences. Adv. Ecol. Res. 23:188-261

Link, S.O., H. Bolton, Jr., M.E. Thiede, and W.H. Rickard. 1995. Responses of downy brome to nitrogen and water. J. Range Manage. 48:290-297.

Mack, R.N. 1981. Invasions of Bromus tectorum L. into western North American: an ecological chronicle. Agro-ecosystems 7:145-165.

Masters, R.A. and R.L. Sheley. 2001. Principles and practices for managing rangeland invasive plants. J. Range Manage. 54:502-517.

McGraw, J.B. and F.S. Chapin, III. 1989. Competitive ability and adaptation to fertile and infertile soils in two Eriophorum species. Ecol. 70:736-749.

McLendon, T. and E.F. Redente. 1991 Nitrogen and phosphorus effects on secondary succession dynamics on a semi-arid sagebrush site. Ecol. 72:2016-2024.

McLendon, T. and E.F. Redente. 1992. Effects of nitrogen limitation on species replacement dynamics during early succession on a semiarid sagebrush site. Oecologia 91:312-317.

Melgoza, G., R.S. Nowak, and R.J. Tausch. 1990. Soil water exploitation after fire: competition between Bromus tectorum (cheatgrass) and two native species. Oecologia 83:7-13.

Milberg, P., B.B. Lamont, and M.A. PérezFernández. 1999. Survival and growth of native and exotic composites in response to a nutrient gradient. Plant Ecol. 145:125-132.

Morecroft, M.D., E.K. Sellers, and J.A. Lee. 1994. An experimental investigation into the effects of atmospheric nitrogen deposition on two semi-natural grasslands. J. Ecol. 82:475-483

Parrish, J.A.D. and F.A. Bazzaz. 1982. Competitive interactions in plant communities of different successional ages. Ecol. 63:314-320

Paschke, M.W., T. McLendon, and E.F. Redente. 2000. Nitrogen availability and old-field succession in a shortgrass steppe. Ecosystems 3:144-158.

Poorter, H., C. Remkes, and H. Lambers. 1990. Carbon and nitrogen ecology of 24 wild species differing in relative growth rate. Plant Physiol. 94:621-627.

Redente, E.F., J.E. Friedlander, and T. McLendon. 1992. Response of early and late semiarid seral species to nitrogen and phosphorus gradients. Plant Soil 140:127-135.

Schläpfer, B. and P. Ryser. 1996. Leaf and root turnover of three ecologically contrasting grass species in relation to their performance along a productivity gradient. Oikos 75:398-406

Snyman, H.A. 2002. Short-term response of rangeland botanical composition and productivity to fertilization ( $\mathrm{N}$ and $\mathrm{P}$ ) in a semi-arid climate of South Africa. J. Arid. Environ. 50:167-183.

Svejcar, T. and R. Sheley. 2001. Nitrogen dynamics in perennial- and annual-dominated arid rangeland. J. Arid. Environ. 47:33-46.

Tilman, D. 1982. Resource competition and community structure. Monographs in population biology 17. Princeton Univ. Press, Princeton, N.J.

Tilman, D. 1984. Plant dominance along an experimental nutrient gradient. Ecol. 65:1445-1453.

Tilman, D. 1987. Secondary succession and the pattern of plant dominance along experimental nitrogen gradients. Ecol. Monogr. 57:189-214.

Tilman, D. 1988. Plant strategies and the structure and dynamics of plant communities. Princeton Univ. Press, Princeton, N.J.

Tilman, D. and D.A. Wedin. 1991. Dynamics of nitrogen competition between successional grasses. Ecol. 72:685-700.

Trickler, D.L., D.T. Hall, C.D. Franks, S.K. Ferguson, L.B. Campbell, P.J. Savage, and J.E. Brewer. 2000. Soil survey of Tooele area, Utah. United States Government Printing Office, Washington D.C. 
van der Werf, A., M. van Nuenen, A.J. Visser, and H. Lambers. 1993a. Contribution of physiological and morphological plant traits to a species' competitive ability at high and low nitrogen supply. Oecologia 94:434-440.

van der Werf, A., A.J. Visser, F. Schieving, and H. Lambers. 1993b. Evidence for optimal partitioning of biomass and nitrogen at a range of nitrogen availabilities for fast and slow-growing species. Funct. Ecol. 7:63-74.

Vitousek, P.M., J.D. Aber, R.W. Howarth, G.E. Likens, P.A. Matson, D.W. Schindler, W.H. Schlesinger, and D. Tilman. 1997. Human alteration of the global nitrogen cycle: sources and consequences. Ecol. Appl. 7:737-750.
Wilson, A.M., G.A. Harris, and D.H. Gates. 1966. Fertilization of mixed cheatgrass-bluebunch wheatgrass stands. J. Range Manage. 19:134-137.

Wilson, A.M., D.E. Wondercheck, and C.J. Goebel. 1974. Responses of range grass seeds to winter environments. J. Range Manage. 32:209-213.

Wilson, S.D. and A.K. Gerry. 1995. Strategies for mixed-grass prairie restoration: herbicide, tilling, and nitrogen manipulation. Rest. Ecol. 3:290--298.

Young, J.A. 1992. Ecology and management of medusahead (Taeniatherum caput medusae ssp. asperum [Simk.] Melderis). Great Basin Natur. 52:245-252.
Young, J.A., R.R. Blank, and W.S Longland. 1995. Nitrogen enrichmentimmobilization to control succession in arid land plant communities. J. Arid Land Stud. 5S:57-60.

Young, J.A., C.D. Clements, and R.R. Blank. 1997. Influence of nitrogen on antelope bitterbrush seedling establishment. J. Range Manage. 50:536-540.

Young, J.A., J.D. Trent, R.R. Blank, and D.E. Palmquist. 1998. Nitrogen interactions with medusahead (Taeniatherum caputmedusae ssp. asperum) seedbanks. Weed Sci. 46:191-195. 